The Common Agricultural Policy of the European Union the present and the future

EU Member States

point of view 



\section{INSTITUTE OF AGRICULTURAL AND FOOD ECONOMICS NATIONAL RESEARCH INSTITUTE}

\section{The Common Agricultural Policy of the European Union - the present and the future}

\section{EU Member States point of view}

Editors:

dr Marek Wigier

prof. dr hab. Andrzej Kowalski

Proceedings of the International Scientific Conference

"The Common Agricultural Policy of the European Union - the present and the future" Multi-Annual Programme 2015-2019

"The Polish and the EU agricultures 2020+. Challenges, chances, threats, proposals" 5-7 December 2017 Stare Jabłonki, Poland

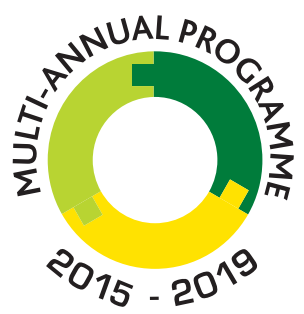

THE POLISH AND THE EU AGRICULTURES 2020+ CHALLENGES, CHANCES, THREATS, PROPOSALS

Warsaw 2018 
This monograph was prepared under the Multi-Annual Programme 2015-2019

"The Polish and the EU agricultures 2020+. Challenges, chances, threats, proposals".

The publication is a collection of selected papers delivered at the 22th edition of the International Scientific Conference organized by the Institute of Agricultural and Food Economics - National Research Institute. The theme of the conference was "The Common Agricultural Policy of the European Union the present and the future. The conference was placed on 5-7 December 2017 in Stary Jabłonki in Poland. Common Agricultural Policy was and still is one of the key pillars of European integration. Published in two volumes materials refer directly to the current and future of the CAP in EU and non EU member states, the strategic objectives and principles of agricultural policy for the agri-food sector and rural areas, address the issues of equilibrium between agriculture, forestry and land use, relate to the dilemmas for the EU budget and the CAP after 2020, CAP instruments and their adjustment, transformations of the rural economy and programming of the rural and agricultural policy, as well as productivity and production efficiency and tensions between sectoral action and between different models of territorial activities.

In the Scientific Committee of the Conference was participated: Prof. Andrzej Kowalski (IAFE-NRI, Poland), Prof. Drago Cvijanonivić (University of Kragujevac, Serbia), Prof. Thomas Doucha (IAEI, Czech Republic), Noureddin Driouech, PhD (CIHEAM, Italy), Prof. Szczepan Figiel (IAFE-NRI, Poland), Prof. Masahiko Gemma (Waseda University, Japan), Prof. Wojciech Józwiak (IAFE-NRI, Poland), Prof. Jacek Kulawik (IAFE-NRI, Poland), Prof. Yuriy Oleksiyovych Lupenko (IAE, Ukraina), Prof. Věra Majerová (CULS, Prague), Prof. Dimitre Nikolov (IAE, Bulgaria), Maire Nurmet, PhD (EMÜ, Estonia), Prof. Gabriel Popescu (ASE, Romania), Norbert Potori, PhD (AKI, Hungary), Prof. Włodzimierz Rembisz (IAFE-NRI, Poland), Piotr Szajner, PhD (IAFE-NRI, Poland), Prof. Alina Sikorska (IAFE-NRI, Poland), Prof. Jonel Subić (IAE, Serbia), Prof. Samuele Trestini (UNIPD, Italy), Prof. Olga Varchenko (Bila Tserkva National Agrarian University, Ukraine), Dipl.-Ing. Klaus Wagner (AWI, Austria), Marek Wigier, PhD (IAFE-NRI, Poland), Prof. Józef St. Zegar (IAFE-NRI, Poland)

In the Organising Committee of the Conference was participated: Małgorzata Bułkowska (IAFE-NRI, Poland), Anna Hankiewicz (IAFE-NRI, Poland), Joanna Jaroszewska (IAFE-NRI, Poland), Joanna Korczak (IAFE-NRI, Poland), Krzysztof Kossakowski (IAFE-NRI, Poland), Irena Mikiewicz (IAFE-NRI, Poland), Małgorzata Mikołajczyk (IAFE-NRI, Poland), Lech Parzuchowski (IAFE-NRI, Poland), Ewa Sierakowska (IAFE-NRI, Poland), Paulina Smakosz (IAFE-NRI, Poland), Leszek Ślipski (IAFE-NRI, Poland), Marek Wigier, PhD (IAFE-NRI, Poland).

Reviewers:

Professor Dimitre Nikolov, Institute of Agricultural Economics, Sofia, Bulgaria

Professor Gabriel Popescu, The Bucharest University of Economic Studies, Bucharest, Romania

Professor Samuele Trestini, University of Padva, Italy

Proofreader

Katarzyna Mikulska

Technical editors:

Joanna Jaroszewska, Barbara Pawtowska, Ewa Sierakowska, Kamila Tomaszewska,

Barbara Walkiewicz

Translated by

Summa Linguae S.A.

Cover Project

Leszek Ślipski

ISBN 978-83-7658-743-1

DOI: $10.30858 / \mathrm{pw} / 9788376587431$

Instytut Ekonomiki Rolnictwa i Gospodarki Żywnościowej

- Państwowy Instytut Badawczy

ul. Świętokrzyska 20, 00-002 Warszawa

tel.: (22) 5054444

faks: (22) 5054636

e-mail:dw@ierigz.waw.pl

http://www.ierigz.waw.pl 


\section{Contents}

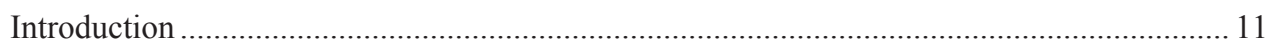

Dr Marek Wigier

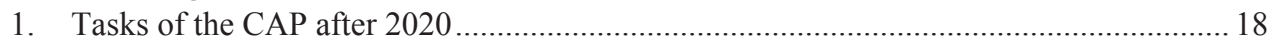

Dr hab. Julian Krzyżanowski

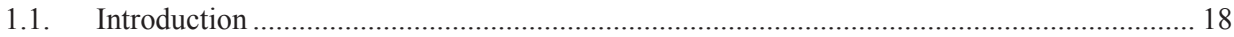

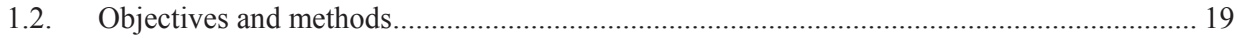

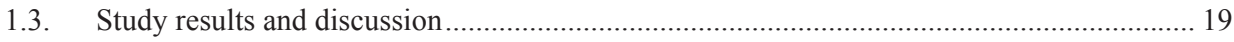

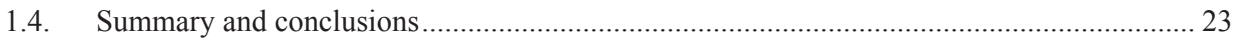

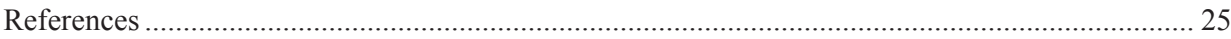

2. An assessment of the regional impacts of post-2020 CAP budgetary cuts on production

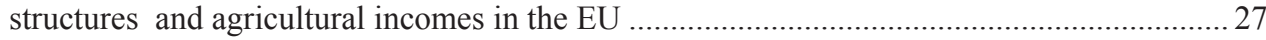

PhD Norbert Potori, PhD János Sávoly, PhD Szabolcs Biró

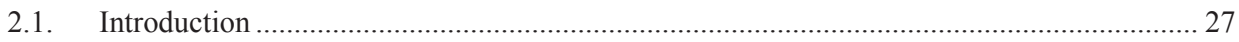

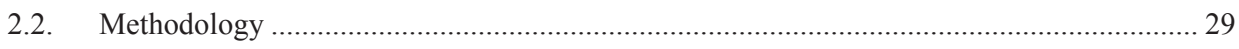

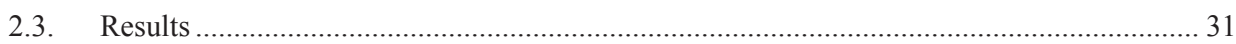

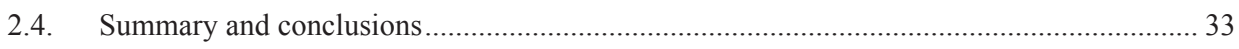

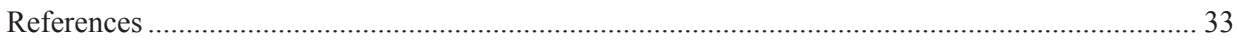

3. Is there room for financial instruments in the Common Agricultural Policy? Casus of

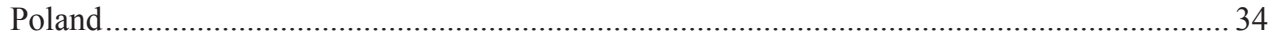

Prof. dr hab. Jacek Kulawik, PhD Barbara Wieliczko, PhD Michat Soliwoda

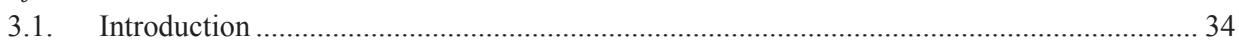

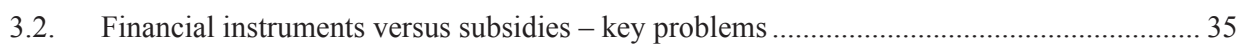

3.3. The use of financial instruments under the EU policy ......................................................... 37

3.4. Example of the use of FI in the 2014-2020 programming period ......................................... 38

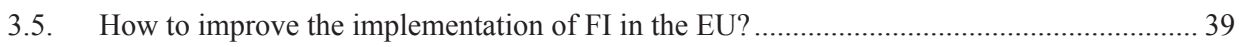

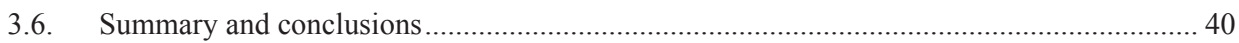

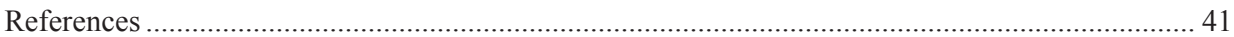

4. The past, present and future of the CAP - the Hungarian viewpoint ............................. 43

Dr Tamás Mizik

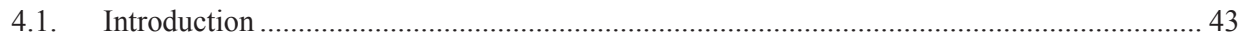

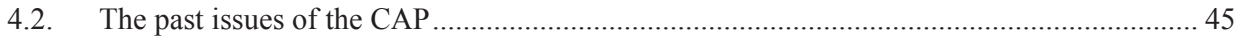

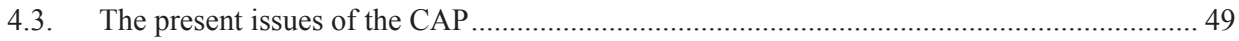

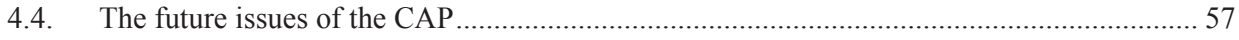

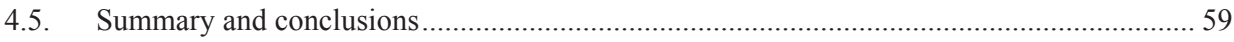

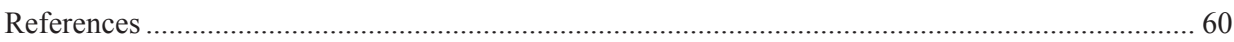


5. Going beyond the Rural Development Programme: a Master Plan for Austria's rural areas in the framework of the CAP

Dip.-Ing. Klaus Wagner

5.1. Introduction

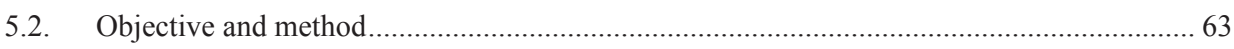

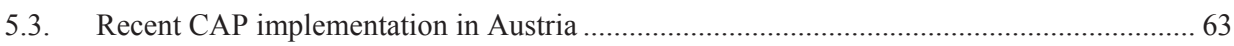

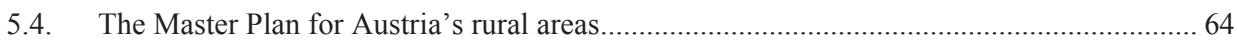

5.5. CAP in the system of the EU policy objectives and in the view of regional science

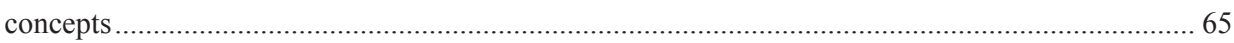

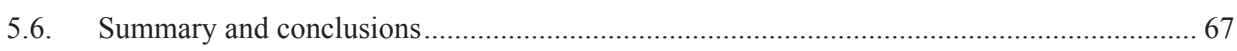

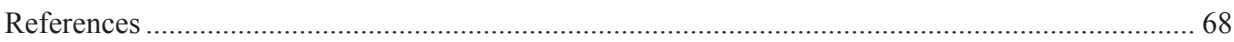

6. Possibilities to connect the Romanian agricultural research to the market requirements 69 Prof. Gabriel Popescu

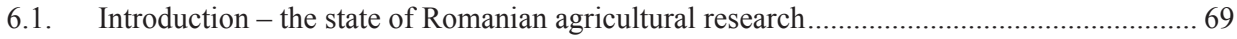

6.2. The problems faced by agricultural research since 1990 ..................................................... 71

6.3. Possible solutions for the recovery of Romanian agricultural research ................................ 76

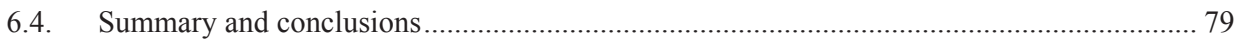

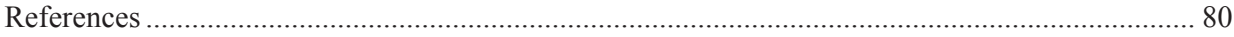

7. Price relationships of the production factors as exogenous determinants of production in agriculture.

Prof. dr hab. Włodzimierz Rembisz, PhD Adam Waszkowski

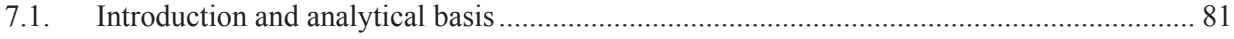

7.2. Relationships of prices of the capital, labour and land factors - hypothetical approach...... 83

7.3. Relationships of prices of the capital, labour and land factors - empirical approach .......... 84

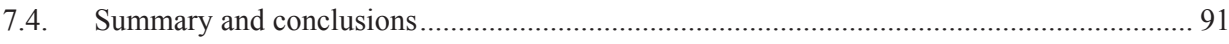

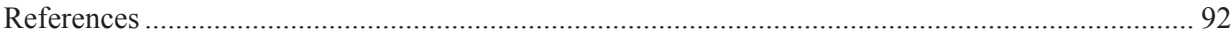

8. Effects of direct payments on agricultural development in Bulgaria ............................. 93 PhD Bozhidar Ivanov

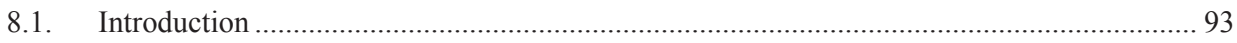

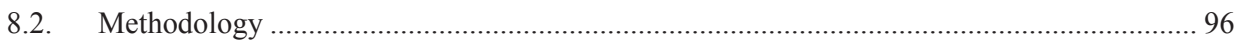

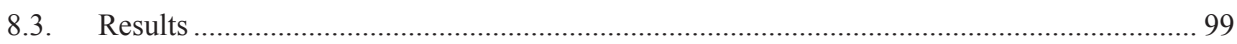

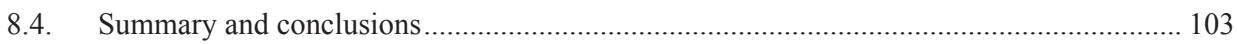

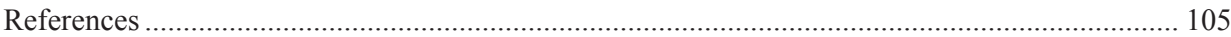

9. Re-adjusting risk management within the CAP: evidences on the implementation of the

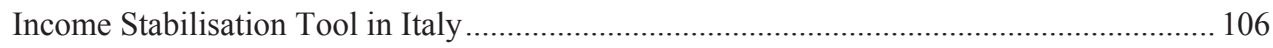
Prof. Samuele Trestini, PhD Elisa Giampietri

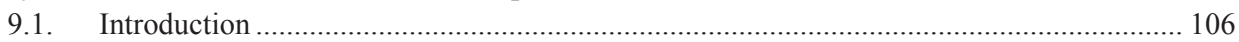

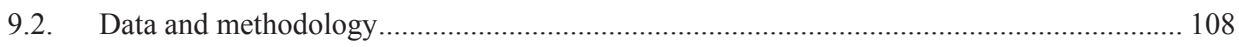




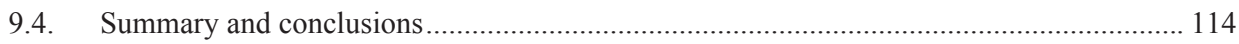

References

10. Comparison of risk management tools under the CAP of the EU, the US Farm Bill

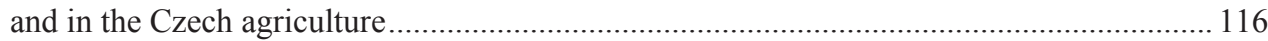
Ing. Václav Vilhelm, CSc., Ing. Sumudu Namali Gouri Boyinová, PhD Jindřich Špička

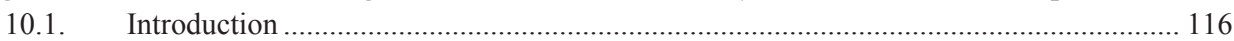

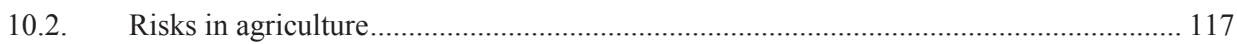

10.3. Risk management policy in the United States Farm Bill 2014 _..................................... 118

10.4. Risk management policy of the European Union's CAP ................................................ 119

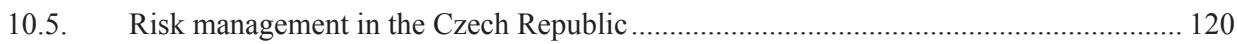

10.6. Comparative analysis of risk management policies ........................................................ 121

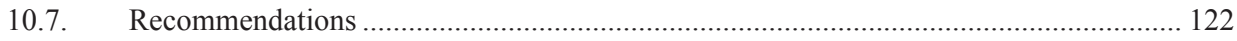

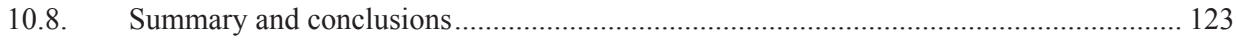

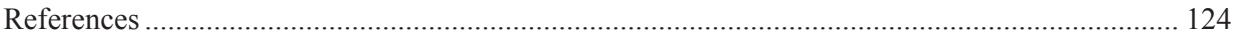

11. Factors determining the crop insurance level in Poland taking into account the level

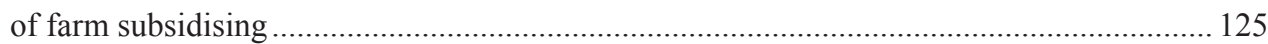

Prof. Adam Was, PhD Pawet Kobus

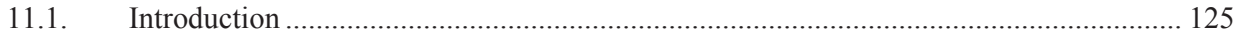

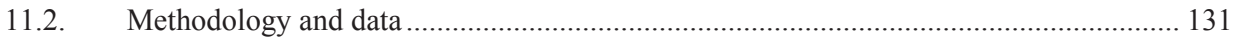

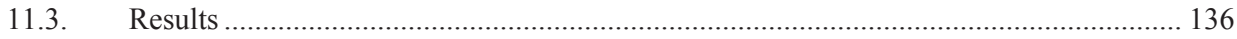

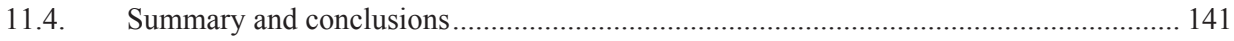

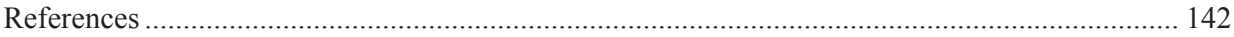

12. Farms and agricultural enterprises for development of sustainable and smart cooperatives: a multifactor approach using digital farm management ............................... 147 Prof. dr habil Adriana Mihnea, Prof. dr Dimitre Nikolov, dr Krasimir Kostenarov

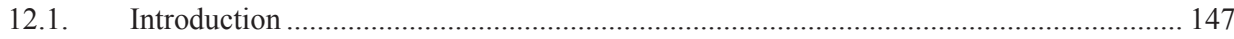

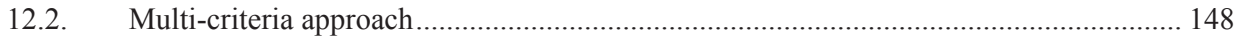

12.3. Construction of Farm Management Model ................................................................ 150

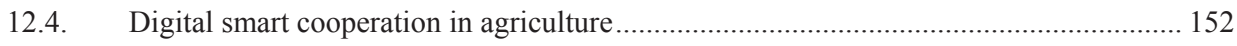

12.5. Application of the ANP Farm Management Model ....................................................... 154

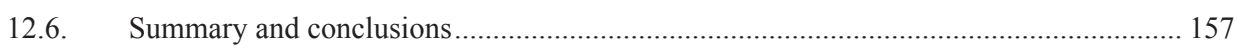

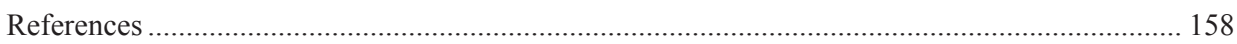

13. Brexit - potential implications for the Polish food sector .............................................. 159

Dr Katarzyna Kosior, Dr Łukasz Ambroziak

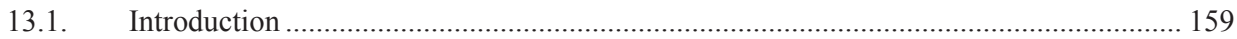

13.2. Negotiations on Brexit - what should be the model of the future relations? ..................... 161

13.3. The future of the EU finances and the CAP in the context of Brexit .............................. 163 
13.4. Impact of possible changes in the CAP budget on the net balance of Poland and transfers to the Polish agriculture.

13.5. The potential impact of Brexit on agri-food trade between Poland and the United

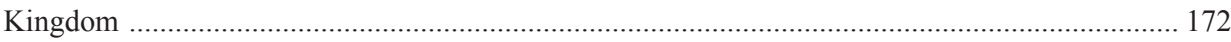

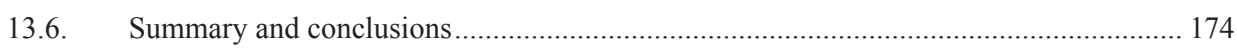

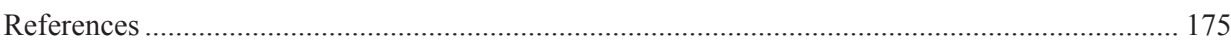

14. The Transatlantic Trade and Investment Partnership (TTIP): a threat or an opportunity for the EU-Mediterranean agriculture and agri-food sector? An exploratory survey ........... 177 Dipl.-Ing. Katja Pietrzyck, PhD Noureddin Driouech, Prof. Brigitte Petersen

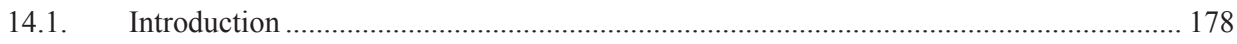

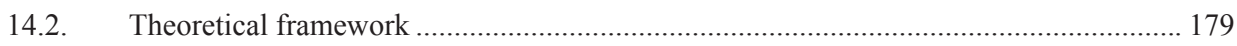

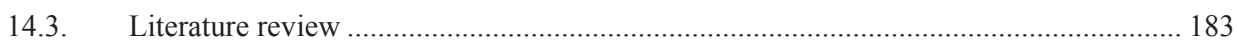

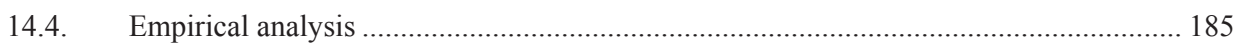

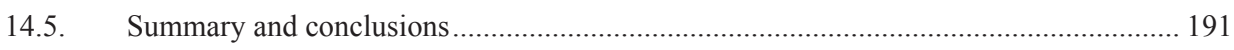

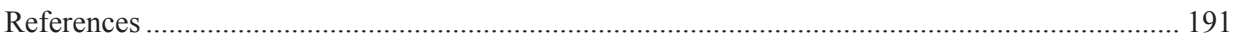

Appendix I: Overview of trade statistics regarding selected products ........................................... 195

15. The concept of short supply chains in the food economy............................................. 196

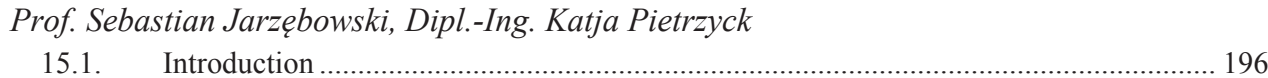

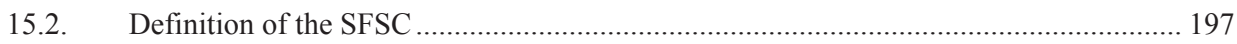

15.3. Development of short supply chains in Europe............................................................. 201

15.4. Global context of European short supply chains ........................................................... 205

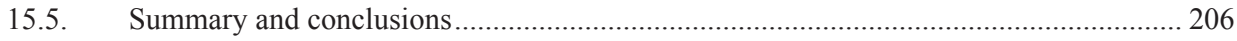

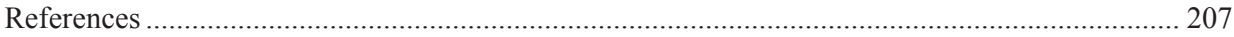

16. The CAP implementation in Wallonia - today performance and questions for the future -

A brief supplementary comment from Warmia and Mazury perspective............................. 209

PhD Philippe Burny, PhD Benon Gazinski

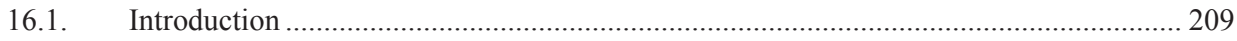

16.2. Implementation of the green payment in Wallonia in 2015 ........................................ 210

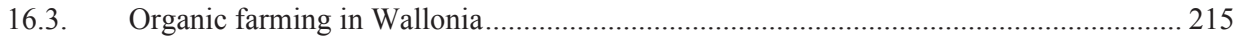

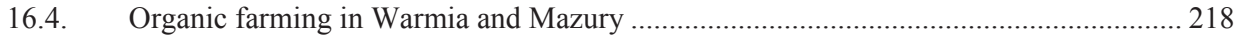

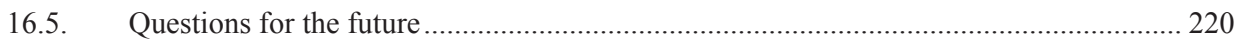

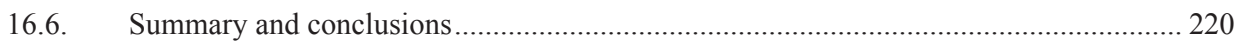

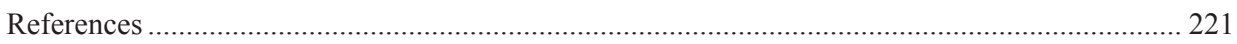

17. Afforestation of agricultural land financed from the RDP 2014-2020 ....................... 224

PhD Marek Zieliński

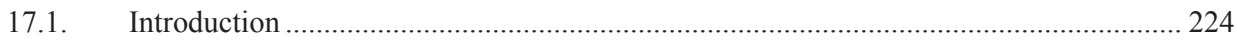

17.2. Natural farming conditions in Poland in regional terms................................................. 225 
17.3. The impact of natural farming conditions in Poland on the economic situation and the possibility of afforestation on farms

17.4. Land afforestation financed from the RDP 2014-2020 in regional terms

17.5. Importance of land afforestations financed under the RDP 2014-2020 in the EU climate policy for 2021-2030.

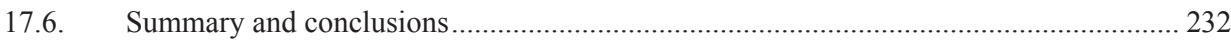

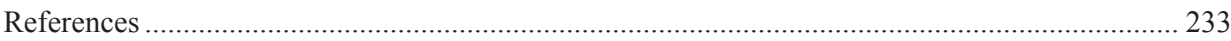

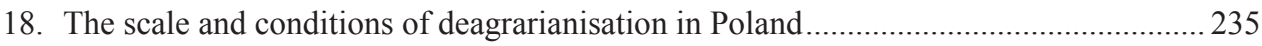

PhD Michat Dudek, PhD Bożena Karwat-Woźniak

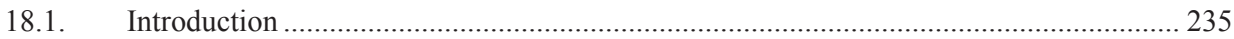

18.2. The conditions of the decrease in employment in agriculture ......................................... 236

18.3. The change in the scale of employment in agriculture in Poland and its conditions....... 238

18.4. The instruments of the Cohesion Policy and agriculture and rural development of the EU

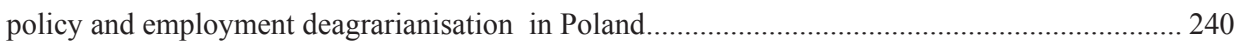

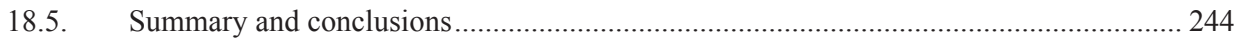

References 245

19. Socio-economic and environmental parameters and results of rural development under the CAP: the case of Bulgaria ................................................................................................ 247 Prof.dr.hab. Julia Doitchinova, Prof.dr.hab. Ivan Kanchev, Ass.Prof. Ralitsa Terziyska PhD, Ass.Prof. Kristina Todorova PhD

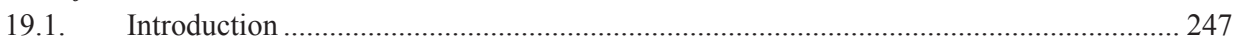

19.2. Changes in Bulgarian rural areas - socio-economic and environmental aspects................ 248

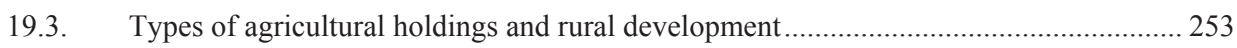

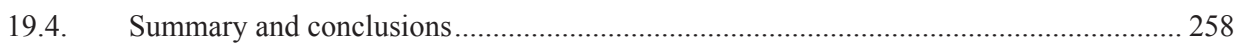

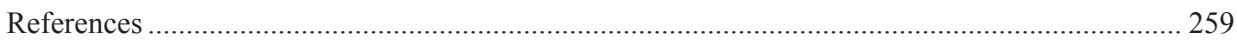

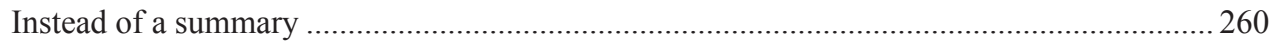

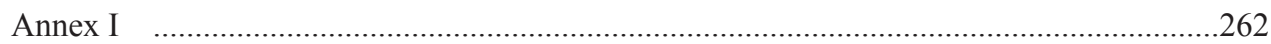




\title{
3. Is there room for financial instruments in the Common Agricultural Policy? Casus of Poland
}

\author{
Prof. dr hab. Jacek Kulawik, PhD Barbara Wieliczko, PhD Michat Soliwoda \\ Institute of Agricultural and Food Economics - National Research Institute, \\ Warsaw, Poland \\ kulawik@ierigz.waw.pl,wieliczko@ierigz.waw.pl, \\ soliwoda@ierigz.waw.pl
}

DOI: $10.30858 / \mathrm{pw} / 9788376587431.3$

\begin{abstract}
A number of new geopolitical conditions, new EU priorities, reform of the euro area with the possibility of establishing a separate budget, fiscal consolidation of most of the EU countries, constitute difficulties in terms of the construction of the EU budget. The aim of the study was to identify the possibility of using financial instruments under the CAP. The analyses concerned mainly Poland. The considerations, illustrated with theoretical and empirical materials, were focused around the following thesis: the permanent domination of the subsidies under CAP and its first pillar radically narrows down the space for using financial instruments. An eclectic approach was applied, using elements of the theory of economics of the public sector, public finances, financial economics and institutional economics. Some justifications of financial instruments do not seem well-founded in theory and probably would not pass the rigorous empirical verification. In order to avoid over-reimbursement and re-promotion of agriculture, it is not advisable to start identifying development barriers to this sector with financial issues. Financial instruments are adjusted mainly to achieve allocation and stabilisation objectives under thr CAP and national agricultural policies. Only larger farms may be interested in financial instruments.
\end{abstract}

Keywords: financial instruments, agricultural finances, EU subsidies, agricultural credit, Common Agricultural Policy

JEL codes: Q14, Q18, G23

\subsection{Introduction}

A series of new geopolitical conditions (including Brexit, the US expectations, articulated by President D. Trump, to increase the contribution of the Europeans to the NATO funding), new EU priorities (common defence policy, combating climate change, protection of external borders and the problem of immigrants), reform of the euro area with the possibility of establishing a separate budget, fiscal consolidation of most of the EU countries, constitute signifi- 
cant and noticeable difficulties in terms of construction of the EU budget. Due to the social pressure of farmers in the countries of the fragmented agrarian structure, the change of course in the case of the "agricultural budget" may turn out to be very difficult. Naturally, it would seem that there should be increased interest in financial instruments (FI).

However, previous experience in the application of financial instruments in rural development programmes is very limited, although their use has been possible for several programming periods. A key drawback is the complexity of their implementation related to the need to involve entities from the financial sector, which means a longer process of preparing a given support instrument for implementation. At the same time, the possibilities and the manner of shaping these instruments are very wide. Until the end of the previous programming period, a significant barrier to the development of the use of these instruments lied in their limitation to a given programming period, as there were no mechanisms to change from one programming period to the next without extinguishing the action, which reduced the possibility of generating multiplier effects and was associated with the re-creation of infrastructure for the implementation of the action in the next period.

Although solutions are introduced in each subsequent programming period based on previous experience, which aimed at facilitating the implementation of financial instruments, complicated implementation procedures remain the key problem. Therefore, changes are proposed to simplify the operation of financial instruments, such as more transparent standards for the selection of financial intermediaries or uniform solutions for grants and financial instruments facilitating to combine these two forms in one project.

The aim of the study is to try to identify the possibility of using financial instruments under the CAP. The analyses will mainly concern Poland. The axis of considerations is as follows: permanent domination of subsidies under the CAP and its first pillar drastically narrows down the space for using financial instruments. The authors applied the eclectic approach, using the method of literature studies, documentary studies, case studies, and - in the discussion - elements of the theory of economics in the public sector, public finances, financial economics and institutional economics. The present analysis is a review study.

\subsection{Financial instruments versus subsidies - key problems}

There is no universally accepted definition of "financial instruments". Accounting, financial reporting, and securities law have developed different classification approaches. For example, the Polish balance sheet law (Article 3, paragraph 1 point 23 of the Act on Accounting; Dz.U. of 1994 No. 121, item 
591) defines financial instruments as "contracts resulting in financial assets being created by one party and financial liabilities or equity instruments on the other". A financial instrument will, therefore, be a financial contract that documents the title of ownership or the right to provide or receive monetary values. Generally, financial instruments, as indicated by typologies of various financial institutions (e.g. BGK), refer to a broad set of loan guarantees, mezzanine (quasi-equity funds), equity and venture funds, microcredits [BGK, 2014].

Table 1 presents the advantages and disadvantages of financial instruments against the background of subsidies. It should be emphasised that the positives include the so-called quantitative and qualitative added value, fairly well recognised by the EU institutions (including the European Investment Bank). In turn, the disadvantages refer to the imperfect mechanisms and ineffective institutional frameworks.

Table 1. Advantages and disadvantages of financial instruments - as compared to subsidies

\begin{tabular}{|c|c|}
\hline Advantages & Disadvantages \\
\hline Quantitative added value & \multirow{4}{*}{$\begin{array}{l}\text { - imperfect, ineffective or- } \\
\text { ganisational model of ex- } \\
\text { isting guarantee funds in } \\
\text { Poland } \\
\text { - creating an institutional, } \\
\text { agriculture-oriented and } \\
\text { rural SME-based system } \\
\text { "from the scratch" } \\
\text { - traditional, neoclassical } \\
\text { investment assessment, } \\
\text { using financial efficiency } \\
\text { criteria }\end{array}$} \\
\hline $\begin{array}{l}\text { - the multiplier effect, } \mathrm{ME} \text { - only credit guarantees } \\
\text { - the leverage effect, } \mathrm{LE} \\
\text { - } \text { the revolving effect, } \mathrm{RE}\end{array}$ & \\
\hline Qualitative added value & \\
\hline $\begin{array}{l}\text { - minimisation of distortions present on the credit market } \\
\text { - innovation of the offer } \\
\text { - strengthening the potential of some entities with low } \\
\text { credit rating } \\
\text { - reducing the imperfections of the market typical only for } \\
\text { the region or only for the agricultural sector } \\
\text { - attracting new sources of knowledge and know-how } \\
\text { - supporting the development of "business mentality" }\end{array}$ & \\
\hline
\end{tabular}

Source: own elaboration on the basis of EIPA-Ecorys-PwC, 2014, Loriz-Hoffmann 2012; European Commission, European Investment Bank 2016, p. 54-55; Kulawik, Soliwoda, Wieliczko, 2017, p. 76-78.

The neoclassical theory draws attention to the information excellence and completeness of financial markets. However, a deeper analysis has shown that in practice we are dealing with incompleteness and imperfection of financial markets. The institutional theory and its successors distinguished the temptation to abuse and negative selection as two important implications of information asymmetry. The occurrence of credit and liquidity restrictions is a symptom of imperfection and incompleteness of financial markets [Stiglitz, 1994; Stiglitz, 2008]. External credit rationing refers to the policy of financial institutions 
which allows for the refusal to grant loans to entities that are too heavily indebted. In turn, internal credit rationing results from various types of barriers inherent in the psyche of a potential borrower: excessive level of financial leverage discourages the use of additional amounts of foreign capital [Kulawik, 1997].

Although there have been and still are numerous empirical studies ${ }^{2}$, referred to even in the work of Ciaian et al. [2012] concerning the identification of determinants of the farms' demand for loans, the estimates of the demand for financial instruments (e.g. for the EU institutions) have remained quite uncertain. This is due to the fact that at the micro level, credit restrictions may have a varied impact on the farmers' decisions regarding the allocation of resources.

Summing up, the arguments for interventionism constitutes the basis for the use of financial instruments under the CAP (for more on the subject see: Kulawik et al. [2017]). In the case of Poland, many prerequisites apply to countries with medium development (Table 2).

Table 2. Rationale for credit intervention in agriculture depending on the level of socio-economic development of the country - developed countries/countries with medium development level

\begin{tabular}{|l|l|}
\hline Developed countries & Countries with medium development level \\
\hline - Imperfection (unreliability, inef- & - Mitigation of credit rationing effects \\
$\begin{array}{l}\text { ficiency) and incompleteness of } \\
\text { financial and credit markets }\end{array}$ & - Elimination of underinvesting in agriculture \\
- Improving the efficiency of non- & - Counteracting the negative effects of the monopo- \\
$\begin{array}{l}\text {-financial markets } \\
\text { - Social justice and inter-regional }\end{array}$ & - Reduction of insolvency costs as well as loss of \\
equal opportunities & credit rating by farmers \\
\hline
\end{tabular}

Source: own elaboration based on literature studies.

\subsection{The use of financial instruments under the EU policy}

Financial instruments, formerly known as financial engineering instruments, are used in the ERDF, ESF and CF funds from the period of 1994-1999, and in the second pillar of the CAP from the 2000-2006 period. There is no significant differentiation between the 'old' and 'new' EU Member States as far as the scale of their application is concerned. In the case of the EAFRD, for the 2007-2013 period, financial instruments amounted to $1.3 \%$ of EAFRD resources at that time. Financial instruments may be used for investment activities, i.e. in the case of RDPs to support investments in agricultural holdings and processing sector entities (Figure 1).

\footnotetext{
${ }^{2}$ Studies conducted in the USA [e.g. Benjamin and Phimister, 2002; Briggeman, Towe and Morehart, 2009] should be mentioned here, as well as in the EU [Petrick and Latruffe, 2003; Latruffe, 2005], referred to by Ciaian et al. [2012]. The set of statistically significant determinants should include: value of own assets, area, profitability, value of fixed assets, level of equity, obtained subsidies (subsidy rate).
} 
Figure 1. Level of funds allocated for the implementation of FI (EUR billion)

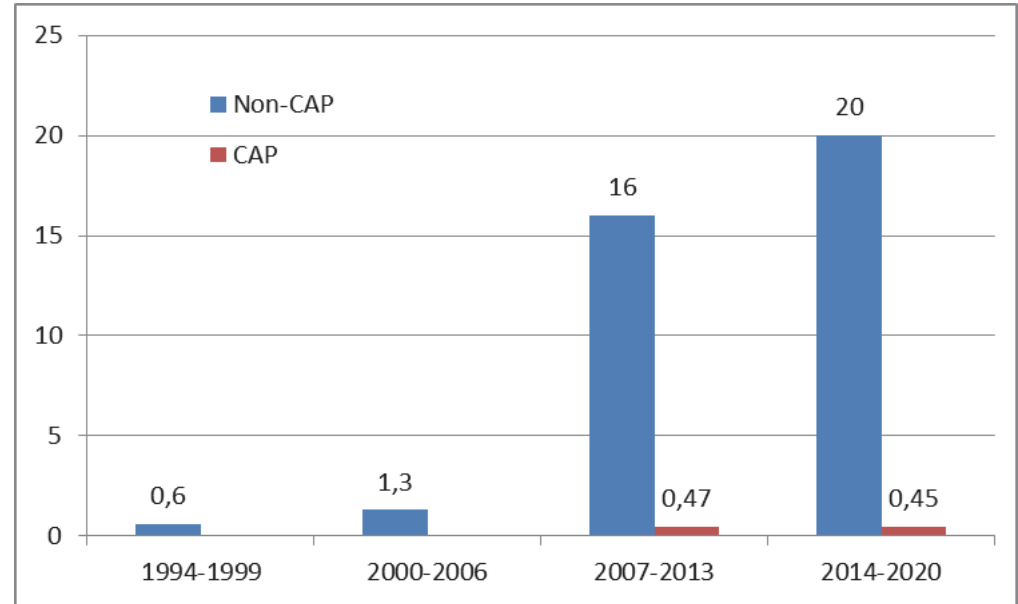

Source: own elaboration on the basis of data from the European Commission [2017a] and European Court of Auditors [2015].

The use of financial instruments is still not popular, although the estimated financial gap is significant. In the EU agriculture alone, it amounts to EUR 7.1-18.6 billion, while in Poland it is EUR 788-1732 million [European Commission, 2018].

\subsection{Example of the use of FI in the 2014-2020 programming period}

French Occitania serves as an example of using a wide range of financial instruments in the current programming period. Based on the previous experience, the scope of application of FI with the use of the ERDF and the EAFRD has been extended. A total support of 5000 SMEs is planned, including agriculture. The budget for this purpose is EUR 143 million (combined resources of both funds, funds from the European Fund for Strategic Investments and public funds from France). It is expected that EUR 900 million will be allocated to entities from the SME sector. The instruments implemented include:

- Loans for seed capital,

- Loan guarantees,

- Co-investment instrument.

With regard to agriculture loan guarantees have been planned for selected measures of the local rural development programme. These activities include: investments in fixed assets; development of farms and economic activity; investments in the development of forest areas and improvement of the viability of forests. Moreover, EUR 27 million of public resources, including EUR 15.81 million in EAFRD funds, will be earmarked for guarantees. It is assumed that on 
the basis of these funds, EUR 135 million will be generated in the form of loans, which means that the leverage needs to be 5 . The guarantees shall reach $80 \%$ of the loan amount, but no more than the established ceiling resulting from the regulations concerning State aid in the agricultural sector. The minimum loan amount is EUR 25,000. Guarantees are granted free of charge, and loans are charged with an average interest rate of $0.4 \%$ lower than the average interest rate [Robino, 2017].

\subsection{How to improve the implementation of FI in the EU?}

In subsequent programming periods, changes are introduced in the functioning of the FI to eliminate shortcomings from the previous period. As part of the changes introduced to the 2014-2020 programming period, mandatory ex ante inspections have been introduced to determine the actual need for this form of support (Table 3).

Table 3. Changes in the functioning of the FI as part of Cohesion Policy in the 2014-2020 programming period in relation to the 2007-2013 period

\begin{tabular}{|c|c|c|}
\hline Specification & $2007-2013$ & 2014-2020 \\
\hline Scope & $\begin{array}{l}\text { Support for enterprises, urban } \\
\text { development, energy efficiency and } \\
\text { renewable energy in construction }\end{array}$ & $\begin{array}{l}\text { Support for all thematic objectives } \\
\text { implemented under the programme }\end{array}$ \\
\hline $\begin{array}{l}\text { Before } \\
\text { creation }\end{array}$ & $\begin{array}{l}\text { Voluntary analysis of the size of the } \\
\text { financial gap for enterprises and at } \\
\text { holding fund level }\end{array}$ & Mandatory ex ante evaluation \\
\hline $\begin{array}{l}\text { Deployment } \\
\text { options }\end{array}$ & $\begin{array}{c}\text { FI at the national or regional level - } \\
\text { tailor-made }\end{array}$ & $\begin{array}{l}\text { FI at the national, regional or interna- } \\
\text { tional level. Individually designed or } \\
\text { ready, loans/guarantees from } \\
\text { the managing authority } \\
\text { Addition to instruments at the EU level }\end{array}$ \\
\hline Payments & $\begin{array}{l}\text { The ability to declare to the Commis- } \\
\text { sion } \\
100 \% \text { of the amount contributed to } \\
\text { the fund - not related to payments to } \\
\text { final beneficiaries }\end{array}$ & $\begin{array}{l}\text { Periodic payments related to the } \\
\text { payment to final beneficiaries. Na- } \\
\text { tional co-financing may be included } \\
\text { in periodic payment applications. }\end{array}$ \\
\hline $\begin{array}{l}\text { Management } \\
\text { costs, fees, } \\
\text { interest rates }\end{array}$ & $\begin{array}{l}\text { Legal basis defined in subsequent } \\
\text { amendments to regulations/ } \\
\text { interpretations specified in three sub- } \\
\text { sequent notes }\end{array}$ & $\begin{array}{l}\text { Detailed solutions available in EU } \\
\text { regulations from the very start }\end{array}$ \\
\hline Reporting & $\begin{array}{l}\text { Mandatory reporting only from } 2011 . \\
\text { Only selected indicators }\end{array}$ & $\begin{array}{l}\text { Mandatory reporting from the very } \\
\text { start. A wide range of indicators }\end{array}$ \\
\hline
\end{tabular}

Source: European Commission [2017b], p. 183.

Still, many solutions applied to FI are not conducive to their widespread use. In connection with this, further changes are proposed regarding various areas of FI functioning (Table 4). 
Table 4. Issues that need simplification and proposals for change

\begin{tabular}{|c|c|}
\hline Area & Proposals \\
\hline $\begin{array}{l}\text { Financial intermediaries and their selection } \\
\text { Public procurement rules hinder implementa- } \\
\text { tion. } \\
\text { The selection process is too long and exces- } \\
\text { sively regulated. } \\
\text { Transparent standards for the selection process } \\
\text { are necessary. }\end{array}$ & $\begin{array}{l}\text { Direct indication in Regulation No. } 1303 / 2013 \\
\text { and amendment of the Public Procurement Di- } \\
\text { rective to unambiguously exempt FI from pub- } \\
\text { lic procurement rules. } \\
\text { Simplification of rules when implementation is } \\
\text { entrusted to national financial institutions that } \\
\text { implement national policy instruments. } \\
\text { Selection procedure containing minimum re- } \\
\text { quirements without the need to apply public } \\
\text { procurement rules. }\end{array}$ \\
\hline $\begin{array}{l}\text { State aid rules applicable to FI } \\
\text { The rules on State aid are applied despite their } \\
\text { complexity, which often leads to illogical re- } \\
\text { sults. } \\
\text { Different application of State aid rules to indi- } \\
\text { vidual parts of the same project or similar } \\
\text { financial projects from the EFSI to centrally } \\
\text { managed programmes. } \\
\text { Unresolved question of repayable assistance - } \\
\text { which rules of State aid should be applied } \\
\text { when repayable assistance is not FI per se, but } \\
\text { does contain some elements of FI and grants? }\end{array}$ & $\begin{array}{l}\text { Simplified State aid rules for FI, modification } \\
\text { of block exemption regulation. } \\
\text { Same rules for grants and FI implemented at } \\
\text { the national level. }\end{array}$ \\
\hline $\begin{array}{l}\text { Combination of grants and FI } \\
\text { Difficulties in linking grants to FI in a single } \\
\text { operation. } \\
\text { Different level of costs and fees, various rules } \\
\text { regarding State aid and the requirement to } \\
\text { maintain separate registers. }\end{array}$ & $\begin{array}{l}\text { Simplified system for two separate operations } \\
\text { or allowing a combination within one. }\end{array}$ \\
\hline
\end{tabular}

Source: Committee of Regions [2016], pp. 7-8 and 12-13.

\subsection{Summary and conclusions}

Key conclusions from the current application of FI and the possibilities of their wider and more effective use and application in Poland are as follows:

- $\quad$ Some justifications of financial instruments do not seem well-founded in theory and probably would not pass the rigorous empirical verification.

- In order to avoid over-reimbursement and re-promotion of agriculture, it is not advisable to start identifying development barriers to this sector with financial issues.

- Before actions are initiated aiming at wider application of financial instruments under the CAP, it should be checked whether the private financial sector will offer at least some of them more effectively. This case is taking place in Poland.

- $\quad$ Financial instruments are adjusted mainly to achieve allocation and stabilisation objectives under the CAP and national agricultural policies. On 
the other hand, their direct impact on the degree of implementation of environmental objectives of these policies is debatable.

- $\quad$ Only larger, market-oriented and development-oriented farms may be interested in financial instruments. Also only such farms are able to efficiently handle the foreign capital offered to them in this way.

- Simplification of the procedures for the application of financial instruments is an important element to increase the demand for such financial instruments. This applies to both the procedures of public administration and financial intermediaries as well as final beneficiaries.

- $\quad$ Previous experience with the implementation of FI under the RDPs is limited, however, all of them (similarly as in the case of other EU funds) indicate that much more time is needed to launch the FI than in the case of grants (subsidies).

\section{References}

1. BGK (2012). Zarządzanie instrumentami pozadotacyjnymi UE - doświadczenia BGK (prezentacja online) Łódź, 24.05.2012. Retrieved from: https://www.mos. gov.pl/g2/big/2012_06/313bfcbd60caef8281fb41b94b5cf35e.ppt (10.05.2017).

2. Blancard, S., Boussemart J.P., Briec W., Kerstens K. (2006). Short- and LongRun Credit Constraints in French Agriculture: A Directional Distance Function Framework Using Expenditure-Constrained Profit Functions. American Journal of Agricultural Economics 88(2), pp. 351-364.

3. Ciaian, P., Fałkowski, J., Kancs, d'A. (2012). Access to credit, factor allocation and farm productivity. Evidence from the CEE transition economies. Agricultural Finance Review, 72(1), pp. 22-47.

4. Committee of Regions (2016). Simplification of the implementation of Cohesion Policy Workshop on Financial instruments in Cohesion Policy on 20 September 2016, Final Report, Brussels.

5. Ecorys (2016). Ocena ex ante celowości zastosowania instrumentów finansowych w ramach Programu Rozwoju Obszarów Wiejskich na lata 2014-2020. Raport dla MRiRW. Warszawa, 30.11.2016. Retrieved from: http://www.minrol.gov.p1/ Ministerstwo/Biuro-Prasowe/Informacje-Prasowe/Ocena-ex-ante-celowoscizastosowania-instrumentow-finansowych-w-ramach-PROW-2014-2020 (10.05.2017).

6. EIPA-Ecorys-PwC (2014). Financial instruments in Cohesion Policy, 2014-2020: Ex-ante assessments. Managing Authority training, June 2014 (for European Commission and European Investment Bank). Retrieved from: http://ec.europa.eu/regional_policy/sources/thefunds/fin_inst/pdf/ex_ante_trainin g.pdf (10.05.2017).

7. European Commission, European Investment Bank (2016). Methodological handbook for implementing an ex-ante assessment of agriculture financial instruments under the EAFRD. EIB, Advisory Services, fi-compass, Luxembourg. 
8. Europejski Bank Inwestycyjny (2015). Europejski Fundusz Rolny na rzecz Rozwoju Obszarów Wiejskich. Instrumenty finansowe. Europejski Bank Inwestycyjny, Luksemburg.

9. European Commission (2017a). Financial instruments under the European Structural and Investment Funds Summaries of the data on the progress made in financing and implementing, the financial instruments for the programming period 2014-2020 in accordance with Article 46 of Regulation (EU) No 1303/2013 of the European Parliament and of the Council. Situation as at 31 December 2016, Brussels, European Commission.

10. European Commission (2017b). My Region, My Europe, Our Future. Seventh report on economic, social and territorial cohesion, Brussels, European Commission.

11.European Commission, European Investment Bank (2016). Methodological handbook for implementing an ex-ante assessment of agriculture financial instruments under the EAFRD. EIB, Advisory Services, fi-compass, Luxembourg.

12. European Commission, European Investment Bank (2018). Financial gap in the EU agricultural sector, Luxembourg, European Investment Bank.

13. European Court of Auditors (2015). Are financial instruments a successful and promising tool in the rural development area? Luxembourg, European Court of Auditors.

14. Kulawik, J. (1997). Rozwój finansowy a wzrost i rozwój ekonomiczny w rolnictwie. Studia i Monografie, nr 83. Warszawa: IERiGŻ.

15.Kulawik, J., Soliwoda, M., Wieliczko, B. (2017). Przesłanki i możliwości szerszego stosowania instrumentów finansowych w WPR i polityce spójności. Zagadnienia Ekonomiki Rolnej, nr 4/2017, pp. 72-94.

16. Kulawik, J. (2000). Makro- i mikroekonomiczne przesłanki oraz skutki interwencjonizmu państwowego w sferze kredytowania rolnictwa. Synteza. Warszawa: IERiGŻ.

17.Loriz-Hoffmann, J., (2012). Financial instruments in rural development 2014-2020: programming and policy elements. Retrieved from: http://enrd.ec.europa.eu/enrdstatic/fms/pdf/B13F3718-F988-2D49-B2C6-C291DA8F0DE6.pdf.

18. Robino, B. (2017). Case studies: Occitanie (France) and Italy. Retrieved from: www.fi-compass.eu.

19. Stiglitz, J.E. (1994). The role of the state in financial markets. Washington, D.C.: The World Bank. Retrieved from: http://documents.worldbank.org/curated/en/ 239281468741290885/The-role-of-the-state-in-financial-markets (10.05.2017).

20. Stiglitz, J.E (2008). Government Failure vs. Market Failure: Principles of Regulation. Retrieved from: http://policydialogue.org/files/events/Stiglitz_Principles_ of_Regulation_2.pdf(10.05.2017).

21. Ustawa o rachunkowości (Act on Accounting). Dz. U. z 1994 r. Nr 121, poz. 591. 